\title{
Conditional Dnmt3b deletion in hippocampal dCA1 impairs recognition memory
}

Qingnuan Kong ${ }^{1,2+}$, Ming $\mathrm{Yu}^{1+}$, Meng Zhang ${ }^{1}$, Chuang Wei ${ }^{1}$, Huating $\mathrm{Gu}^{1}$, Shaoyang $\mathrm{Yu}^{1}$, Wei Sun ${ }^{1}$, Nan $\mathrm{Li}^{1}$ and Yu Zhou ${ }^{1,3^{*}}$

\begin{abstract}
Aim: Active changes in neuronal DNA methylation and demethylation appear to act as controllers of synaptic scaling and glutamate receptor trafficking in learning and memory formation. DNA methyltransferases (DNMTs), including proteins encoded by Dnmt1, Dnmt3a and Dnmt3b, are dominant enzymes carrying out DNA methylation. Our previous study demonstrated the important roles that DNMT1 and DNMT3a play in synaptic function and memory. In this study, we aim to explore the role of DNMT3b and its-mediated DNA methylation in memory processes.

Methods: Dnmt3b was knocked down specifically in dorsal CA1 neurons of adult mice hippocampus by AAV-synCre-GFP virus injection. Behavioral tests were used to evaluate memory performance. Gene expression microarray analysis followed by quantitative RT-PCR were performed to find differential expression genes.

Results: Dnmt36 floxflox mice receiving Cre-virus infection showed impaired novel object-place recognition (NPR) and normal novel object recognition (NOR), in comparison to mice receiving control GFP-virus infection. Microarray analysis revealed differential expression of $\mathrm{K}^{+}$channel subunits in the hippocampus of Dnmt $3 b^{\text {flox fllox }}$ mice receiving Cre-virus injection. Increased Kcne2 expression was confirmed by following qRT-PCR analysis. We also found that NPR training and testing induced up-regulation of hippocampal Dnmt1 and Dnmt3a mRNA expression in control mice, but not in Cre-virus injected mice. Our findings thus demonstrate that conditional Dnmt3b deletion in a subregion of the hippocampus impairs a specific form of recognition memory that is hippocampus-dependent.
\end{abstract}

Keywords: Dnmt3b, Memory, Hippocampus, Object-place recognition

\section{Main text}

It is well-known that DNA methylation alters gene expression without changing DNA sequence, and it plays a vital role in regulating adult brain functions including learning and memory $[1,2]$. Accumulative evidence has revealed

\footnotetext{
*Correspondence: yuzhou7310@gmail.com; yuzhou@qdu.edu.cn

${ }^{\dagger}$ Qingnuan Kong and Ming Yu contributed equally to this work.

'Department of Physiology and Pathophysiology, School of Basic Medical

Sciences, Qingdao University, Qingdao 266071, Shandong, China

${ }^{3}$ Institute of Brain Sciences and Related Disorders, Qingdao University, Qingdao 266071, Shandong, China

Full list of author information is available at the end of the article
}

that DNA methylation alterations in brain neurons dynamically modulates synaptic plasticity and are required for multiple forms of memory formation, for example contextual fear memory, object recognition memory, and spatial memory [1-3]. DNA methylation is catalyzed by DNA methyltransferases (DNMTs), which add methyl to the $5^{\prime}$ position of cytosine $(\mathrm{C})$ to form a 5 -methyl cytosine $(5 \mathrm{mC})$. DNMT1, DNMT3a and DNMT3b are three active DNMTs identified in mammals. DNMT3L enhances the DNA methylation activity of other DNMT3 whereas it is catalytically inactive. It is noted that DNMTs in neurons

(c) The Author(s). 2020 Open Access This article is licensed under a Creative Commons Attribution 4.0 International License, which permits use, sharing, adaptation, distribution and reproduction in any medium or format, as long as you give appropriate credit to the original author(s) and the source, provide a link to the Creative Commons licence, and indicate if changes were made. The images or other third party material in this article are included in the article's Creative Commons licence, unless indicated otherwise in a credit line to the material. If material is not included in the article's Creative Commons licence and your intended use is not permitted by statutory regulation or exceeds the permitted use, you will need to obtain permission directly from the copyright holder. To view a copy of this licence, visit http://creativecommons.org/licenses/by/4.0/. The Creative Commons Public Domain Dedication waiver (http://creativecommons.org/publicdomain/zero/1.0/) applies to the data made available in this article, unless otherwise stated in a credit line to the data. 
are closely associated with learning and memory processes $[4,5]$. Our previous findings showed that double knockout of Dnmt1 and Dnmt3a in $\alpha \mathrm{CaMKII}{ }^{+}$forebrain neurons led to hippocampus-dependent memory impairment [1]. In spite of very limited expression in mature neurons, several studies have suggested that DNMT3b, when concurrently functioning with DNMT1 or DNMT3a to modulate DNA methylation, may also play an important role in controlling gene expression and memory processes [6-8]. Besides, DNMT3b alone has been proven to play specific roles in regulating methylation and certain brain functions. Suicide attempters were linked to Dnmt3b SNP polymorphisms [9]. EPO micro-injected into the hippocampus upregulated Dnmt3b expression and improved spatial learning \& memory in SAMP8 mice [10]. However, its molecular and cellular mechanisms remain unclear. In the present study, we conducted Cre-dependent neuronal
Dnmt3b deletion specifically in CA1 region (dCA1) of the dorsal hippocampus in order to explore memory alterations and underlying molecular mechanisms.

Cre- or Con- virus was delivered to hippocampal dCA1

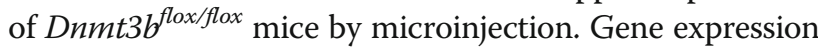
microarray analysis and a following quantitative RT-PCR analysis were performed to explore the differential expression of candidate genes. The detailed methods were described in the Additional file 1. GFP fluorescence indicated that $\mathrm{dCA} 1$ neurons in the hippocampus were successfully transfected at 14 days after the local virus injection (Fig. 1a). Quantitative RT-PCR analysis showed that Dnmt3b mRNA expression in the hippocampus was reduced in Dnmt $3 b^{\text {flox } f l o x}$ mice receiving the Cre-virus injection, while the Dnmt1 and Dnmt3a mRNA expressions were similar between two groups of mice (Fig. 1b). Then we tested whether Cre-dependent Dnmt3b deletion in

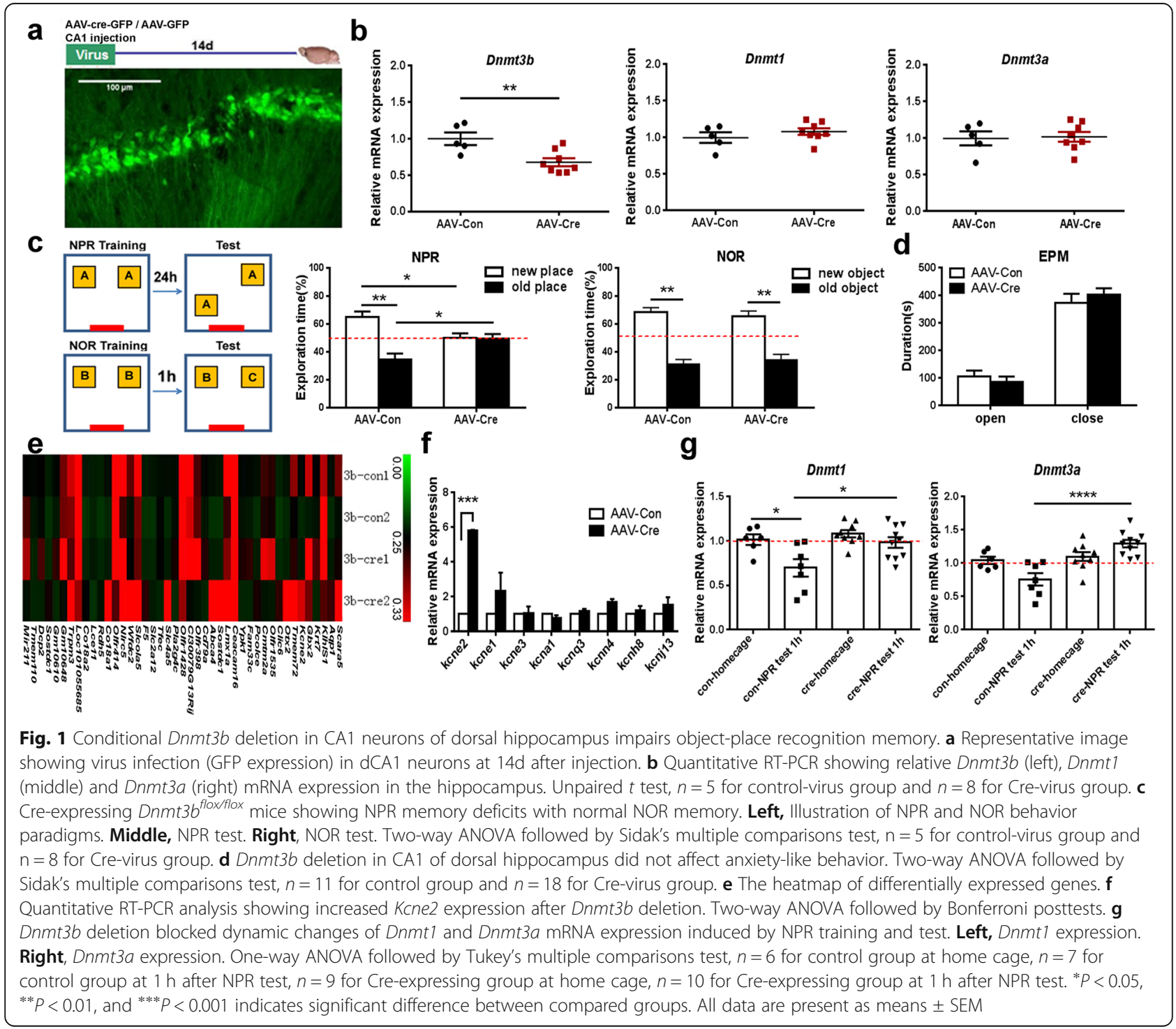




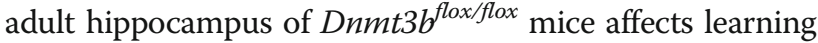

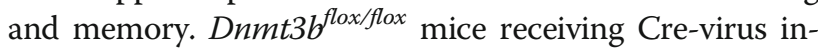
jection exhibited object-place recognition deficits but normal object recognition memory (Fig. 1c). In addition, $D n m t 3 b^{f l o x / f l o x}$ mice receiving Cre-virus injection exhibited normal spatial learning and memory in a Morris water maze task (data not shown). Also, an elevated plus maze test disclosed that Cre-dependent Dnmt3b deletion in CA1 neurons of dorsal hippocampus did not affect anxiety-like behavior of Dnmt3b flox/flox mice (Fig. 1d). It was reported that object-place memory and object memory appear to be dependent on different brain regions. Object-place memory requires the hippocampus for encoding, consolidation and retrieval $[11,12]$, and it is particularly sensitive to manipulations in dorsal CA1 [13]; whereas object memory requires the participation of different brain regions including insular cortex, perirhineal cortex and medial prefrontal cortex [14]. The role of the hippocampus in object recognition has remained controversial [11]. Therefore, with our virus-based, Credependent Dnmt3b deletion system, it might be interesting to test whether Dnmt3b deletion in other brain regions, such as insular cortex or perirhineal cortex, affects object recognition rather than object-place recognition.

To explore the molecular mechanism underlying object-place recognition memory deficits caused by Credependent Dnmt3b deletion in dorsal hippocampal neurons, we extracted total RNA from dorsal hippocampus of Dnmt3b floxfllox mice receiving either Cre- or controlvirus injection. Gene expression microarray analysis showed forty-six differentially expressed genes with folder changes over 1.5 times, including 22 upregulated genes and 24 downregulated genes (Fig. 1e). Among those 46 genes, Kcne 2 expression was significantly upregulated, which was then confirmed by real-time qRTPCR analysis (Fig. 1f). It is reported that KCNE2 modulates neuronal excitability through regulating $\mathrm{Kv}$ channel activity in the brain [15], although so far there is no direct evidence proving that KCNE family is involved in neuron plasticity and memory. Therefore, we presumed that the upregulation of Kcne2 expression caused by Dnmt3b deletion in dorsal hippocampus might contribute to the NPR deficits observed in Dnmt3b flox flox mice.

Moreover, we found that, object-place recognition learning and memory process was accompanied by dynamic changes of hippocampal Dnmt1 and Dnmt3a mRNA expression in Dnmt3b flox/flox mice receiving

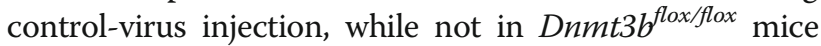
receiving Cre-virus injection (Fig. 1g). Dnmt1 mRNA expression in the hippocampus of control Dnmt $3 b^{\text {flox fllox }}$ mice significantly decreased after NPR training and testing (Fig. 1g). However, NPR training and testing did not change the Dnmt1 mRNA level in Dnmt $3 b^{\text {flox/flox }}$ mice receiving Cre-virus injection (Fig. 1g). After NPR training and testing, hippocampal Dnmt1 mRNA expression showed significant difference between $D n m t 3 b^{f l o x f l o x}$ mice receiving Cre-virus and Dnmt $3 b^{\text {floxfflox }}$ mice receiving control-virus injection (Fig. 1g). Similar to dynamic change of Dnmt1, Dnmt3a mRNA expression also slightly decreased following NPR training and testing in control Dnmt $3 b^{\text {flox } f l o x}$ mice, but not in Cre-expressing $D n m t 3 b^{\text {floxfflox }}$ mice. Significantly, Dnmt $3 b^{\text {flox } f l o x}$ mice infected by Cre-virus displayed even higher hippocampal

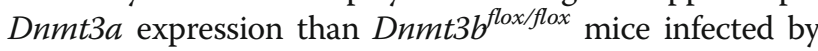
control-virus (Fig. 1g). Therefore, our results demonstrated that Cre-dependent Dnmt3b deletion blocked dynamic down-regulation of Dnmt1 and Dnmt3a mRNA expression induced by NPR training and testing, which may also contribute to NPR deficits observed in those Dnmt $3 b^{\text {flox } f l o x}$ mice.

In conclusion, our study suggests that DNMT3b in mature neurons of dorsal hippocampus especially at the CA1 region plays an important role in regulating objectplace recognition memory. We postulate that Kcne2 is one of the important genes targeted by DNMT3b-mediated DNA methylation, therefore contributes to objectplace recognition process.

\section{Supplementary information}

Supplementary information accompanies this paper at https://doi.org/10. 1186/s13041-020-00574-9.

\section{Additional file 1.}

\section{Abbreviations \\ AAV: Adeno-associated virus; DNMT: DNA methyltransferases; \\ EPO: Erythropoietin; GFP: Green fluorescent protein; Kcne: Potassium voltage- gated channel subfamily E member 2; NOR: Novel object recognition; NPR: Novel object-place recognition; PCR: Polymerase chain reaction; SAMP8: Senescence accelerated mouse-prone 8; SNP: Single nucleotide polymorphism; aCaMKII: $\mathrm{Ca}^{2+} /{ }^{2+}$ almodulin-dependent protein kinase Ila}

\section{Acknowledgements}

We thank Xiaomin Sun and Xue Mi for the animal husbandry. We thanks Dr. Guodong Li for critical reading and Ms. Jennifer Li for native language editing.

\section{Authors' contributions}

YZ designed and supervised the experiments. QK, MY, MZ, CW and HG performed the experiments. SY, WS and NL did data analysis. QK and YZ wrote the manuscript. All authors read and approved the final manuscript.

\section{Funding}

This work was supported by NNSFC (Grant no. 91732110 and 81070881 to YZ, 31900854 to MY), and NSFC of SD province (Grant no. 2019GGX101045, ZR2019ZD34 to YZ).

\section{Availability of data and materials}

The detailed methods are described in the Additional file 1.

\section{Ethics approval}

The Chancellor's Animal Research Committee at Qingdao University approved all the experiments according to National Institutes of Health guideline. 


\section{Consent for publication}

Not applicable.

\section{Competing interests}

The authors declare that they have no competing interests.

\section{Author details}

'Department of Physiology and Pathophysiology, School of Basic Medical Sciences, Qingdao University, Qingdao 266071, Shandong, China.

${ }^{2}$ Department of Pathology, Qingdao Municipal hospital, Qingdao University, Qingdao 266071, Shandong, China. ${ }^{3}$ Institute of Brain Sciences and Related

Disorders, Qingdao University, Qingdao 266071, Shandong, China.

Received: 6 January 2020 Accepted: 27 February 2020

Published online: 17 March 2020

\section{References}

1. Feng J, Zhou Y, Campbell SL, Le T, Li E, Sweatt JD, et al. Dnmt1 and Dnmt3a maintain DNA methylation and regulate synaptic function in adult forebrain neurons. Nat Neurosci. 2010;13:423-30.

2. Yu NK, Baek SH, Kaang BK. DNA methylation-mediated control of learning and memory. Mol Brain. 2011;4:5.

3. Oliveira AM. DNA methylation: a permissive mark in memory formation and maintenance. Learn Mem. 2016;23:587-93.

4. Bayraktar G, Kreutz MR. Neuronal DNA Methyltransferases: epigenetic mediators between synaptic activity and gene expression? Neuroscientist. 2018;24:171-85.

5. Cui D, Xu X. DNA Methyltransferases, DNA methylation, and age-associated cognitive function. Int J Mol Sci. 2018;19:1315.

6. Miller CA, Sweatt JD. Covalent modification of DNA regulates memory formation. Neuron. 2007:53:857-69.

7. Kumar R, Jain V, Kushwah N, Dheer A, Mishra KP, Prasad D, et al. Role of DNA methylation in hypobaric hypoxia-induced Neurodegeneration and spatial memory impairment. Ann Neurosci. 2018;25:191-200.

8. Gagliardi M, Strazzullo M, Matarazzo MR. DNMT3B functions: novel insights from human disease. Front Cell Dev Biol. 2018;6:140.

9. Murphy TM, Mullins N, Ryan M, Foster T, Kelly C, McClelland R, et al. Genetic variation in DNMT3B and increased global DNA methylation is associated with suicide attempts in psychiatric patients. Genes Brain Behav. 2013;12: 125-32.

10. Yu N, Liu J, Yi G, Ye F, Xiao J, Guo F. DNA methylation is necessary for erythropoietin to improve spatial learning and memory in SAMP8 mice. Exp Gerontol. 2015;69:111-5.

11. Haettig J, Stefanko DP, Multani ML, Figueroa DX, McQuown SC, Wood MA. HDAC inhibition modulates hippocampus-dependent long-term memory for object location in a CBP-dependent manner. Learn Mem. 2011;18:71-9.

12. Cui L, Sun W, Yu M, Li N, Guo L, Gu H, et al. Disrupted-in-schizophrenia1 (DISC1) L100P mutation alters synaptic transmission and plasticity in the hippocampus and causes recognition memory deficits. Mol Brain. 2016;9:89.

13. Vogel-Ciernia A, Matheos DP, Barrett RM, Kramar EA, Azzawi S, Chen Y, et al. The neuron-specific chromatin regulatory subunit BAF53b is necessary for synaptic plasticity and memory. Nat Neurosci. 2013;16:552-61.

14. Tanimizu T, Kono K, Kida S. Brain networks activated to form object recognition memory. Brain Res Bull. 2018;141:27-34.

15. Manville RW, Abbott GW. Teamwork: ion channels and transporters join forces in the brain. Neuropharmacology. 2019;161:107601.

\section{Publisher's Note}

Springer Nature remains neutral with regard to jurisdictional claims in published maps and institutional affiliations.

\section{Ready to submit your research? Choose BMC and benefit from}

- fast, convenient online submission

- thorough peer review by experienced researchers in your field

- rapid publication on acceptance

- support for research data, including large and complex data types

- gold Open Access which fosters wider collaboration and increased citations

- maximum visibility for your research: over $100 \mathrm{M}$ website views per year

At BMC, research is always in progress.

Learn more biomedcentral.com/submissions 